\title{
LIGHT EMITTING DIODE (LED) USE IN ARTIFICIAL LIGHTING FOR BROILER CHICKEN PRODUCTION
}

\author{
MAYARA R. DE SANTANA ${ }^{1}$, RODRIGO G. GARCIA ${ }^{2}$, IRENILZA DE A. NAAS ${ }^{3}$, \\ IBIARA C. DE L. A. PAZ ${ }^{4}$, FABIANA R. CALDARA ${ }^{5}$, BRUNA BARRETO ${ }^{6}$
}

\begin{abstract}
Light emitting diode (LED) has been used in commercial poultry industry by presenting superior energy savings and providing feasibility on production process. The objective of this research was to evaluate performance and carcass yield of broiler chickens exposed to different LED colors compared with fluorescent lamps. For that, two experiments (E1 and E2) were performed and 2,646 Cobb ${ }^{\circledR}$ chickens were used. In experiment E1, male birds were exposed to 20 lux artificial lighting with red, yellow, blue, and white LED bulbs; and fluorescent bulb. In experiment E2, male and female birds were exposed to 15 lux artificial lighting with red and blue LED bulbs; and fluorescent bulb. Cumulative weight gain (kg), feed intake (kg), feed conversion, hot carcass weight (kg), carcass yield (\%), and breast and thigh + drumstick yield (\%) were used as response variables. Results showed no difference ( $p>0.05)$ among treatments for performance, carcass yield, and cut yield in experiment E1. In experiment E2 there was only difference between genders $(\mathrm{p} \leq 0.05)$ and males showed higher total weight gain, feed intake, hot carcass weight and thigh + drumstick yield. Different LED color use had same effect as fluorescent lights on broiler performance and carcass yield.
\end{abstract}

KEYWORDS: poultry, production, artificial lighting, LED

\section{DIODO EMISSOR DE LUZ (LED) NA ILUMINAÇÃO ARTIFICIAL DE FRANGOS DE CORTE}

RESUMO: A utilização de lâmpadas de diodo emissor de luz (LED) tem-se destacado na avicultura por apresentar economia de energia e proporcionar viabilidade do processo de criação. O objetivo desta pesquisa foi avaliar o desempenho e o rendimento de carcaça de frangos de corte expostos a diferentes cores de LED, em comparação às lâmpadas fluorescentes. Para isso, foram realizados dois experimentos (E1 e E2) utilizando 2.646 aves da linhagem Cobb®, em que, no experimento E1, as aves (machos) foram expostas à iluminação artificial (20 lux) com LED vermelho, amarelo, azul, branco e lâmpada fluorescente, e no experimento E2, as aves (machos e fêmeas) foram expostas à iluminação artificial (15 lux) com LED vermelho e azul, e lâmpada fluorescente. Como variáveis respostas, foram medidos o ganho de peso acumulado (kg), o consumo de ração $(\mathrm{kg})$, a conversão alimentar, o peso de carcaça quente $(\mathrm{kg})$, o rendimento de carcaça (\%) e de peito, e a coxa-sobrecoxa (\%). Os resultados mostraram que não houve diferença $(p>0,05)$ entre os tratamentos para desempenho e rendimento de carcaça e cortes, no experimento E1. No experimento $E 2$, houve diferença apenas entre os sexos $(p \leq 0,05)$, com machos apresentando maior ganho de peso acumulado, maior consumo de ração, maior peso de carcaça quente e maior rendimento de coxa-sobrecoxa. Pode-se concluir que a utilização de LED, nas diferentes cores, apresentou o mesmo efeito das lâmpadas fluorescentes sobre o desempenho e o rendimento de carcaça de frangos de corte.

PALAVRAS-CHAVE: avicultura, produção, iluminação artificial, LED.

\footnotetext{
${ }^{1}$ Zootecnista, Doutoranda em Zootecnia, Departamento de Melhoramento e Nutrição Animal, FMVZ/UNESP, Botucatu-SP, Fone: (14) 98197-1066, mayara_mf@hotmail.com

${ }^{2}$ Zootecnista, Prof. Doutor, Faculdade de Ciências Agrárias, FCA/UFGD, Dourados-MS, rodrigogarcia@ufgd.edu.br

${ }^{3}$ Eng. . Civil, Pesquisador Visitante Sênior PVNS-CAPES, FCA/UFGD, Dourados-MS, irenilza@gmail.com

${ }^{4}$ Zootecnista, Profa. Doutora, Departamento de Produção Animal, FMVZ/UNESP, Botucatu-MS,ibiarapaz@fmvz.unesp.br

${ }^{5}$ Zootecnista, Prof ${ }^{a}$. Doutora, Faculdade de Ciências Agrárias, FCA/UFGD, Dourados-MS, fabianacaldara@ufgd.edu.br

${ }^{6}$ Graduanda em Zootecnia, Faculdade de Ciências Agrárias, FCA/UFGD, Dourados-MS, bruna-b@hotmail.com

Recebido pelo Conselho Editorial em: 15-5-2013
}

Aprovado pelo Conselho Editorial em: 5-12-2013 


\section{INTRODUCTION}

Artificial lighting is a tool used in poultry production and it aims to improve food and water intake and consequent growth, and hence flock economic feasibility (MENDES et al., 2010). Poultry light programs are prepared in accordance with bird metabolism changes at different ages, and they vary according to final weight required by the market. One of the biggest challenges in broiler production is related to power consumption, which substantially increases production cost (YANAGI JUNIOR et al., 2011; PEREIRA et al., 2012). Thus, the ideal light program provides maximum production and reduces energy expenses.

Currently, LED use in broiler production has demonstrated high luminous efficiency, less power consumption, and longer service life when compared to incandescent and fluorescent lamps (CAO et al., 2012). Evaluation results of different LED colors for artificial lighting system in poultry production and their physiological and production effects are found in literature (XIE et al., 2009; ZHANG et al., 2012; MENDES et al., 2013). According to MENDES et al. (2010) quality, intensity, photoperiod, and light color may interfere with bird behavior and development. Photosensitive parts of bird brain connected to pineal gland are stimulated by light that reaches the retina receptors; and, therefore, are influenced by environment light (JIN et al., 2010).

PAIXÃO et al. (2011) studied two light sources (fluorescent and white LED) and observed no difference in broiler performance. CAO et al. (2008) evaluated four LED colors (white, red, blue and green) in poultry production and found different results. Those results indicated that birds kept under blue light showed higher body weight at 21-48 day growth. ROZEMBOIM et al. (1999) also found higher body weight in broilers exposed to blue and green light at 34 day growth, but found no difference in feed conversion throughout total rearing period.

The objective of this research was to evaluate broiler performance and carcass yield submitted to different LED colors compared to fluorescent lamps.

\section{MATERIAL AND METHODS}

This research was carried out at the Experimental Poultry Section of the College of Agricultural Sciences from Federal University of Grande Dourados - FCA / UFGD. The local climate classification according to Köppen method is Cwa (mesothermal humid climate with hot summers and dry winters), latitude $22^{\circ} 13^{\prime} 18$ " S, longitude $54^{\circ} 48 ' 23^{\prime \prime} \mathrm{W}$, and at $430 \mathrm{~m}$ altitude.

Two experiments, E1 and E2, were developed using an aviary with dimensions of 50 x $10 \mathrm{~m}$, $2.8 \mathrm{~m}$ in height, fiber cement tiles, polypropylene roof isolation, and polypropylene curtains on the side walls. The aviary was divided into 56 boxes with an area of $4.5 \mathrm{~m}^{2}$ each, equipped with bell drinkers, tube feeders, negative pressure tunnel system with evaporative cooling (Mat Cooling) and temperature and humidity automated control.

In the first experiment (E1) 1,350 Cobb ${ }^{\circledR} 500$ strain male pullets were distributed into 25 boxes using a flock density of 12 birds $/ \mathrm{m}^{2}$, and they were reared according to the strain recommendations. A 10 day warming period was performed with infrared lamps, and after the tenth day growth birds were placed in environments with LED lighting and 20 lux compact fluorescent lamps. In experiment E2, 1,296 Cobb ${ }^{\circledR} 500$ strain male and female pullets were divided into 24 boxes, with the same flock density as E1.

Bird handling was similar for both experiments and yellow, red, blue, white LED and compact fluorescent bulb were used in E1. In the case of E2, it was used red, blue LED colors, which are the visible spectrum limits, and 15 lux compact fluorescent (control).

Boxes were sealed on top using black plastic preventing illumination interference from the others. A balanced diet was provided to birds for each production growth stage (pre-starter, starter, grower, and finisher). The lighting program applied on continuous illumination of 23 hours of light per day. 
Broiler performances were weekly measured by registering bird weight (kg), given food amount (kg), and uneaten feed (kg). After 42 day growth, cumulative weight gain (kg), feed intake (kg), and feed conversion throughout the rearing period were calculated. A 0.01-g precision scale was used to weight food; and a $10 \%$ bird sample of each replication was randomly selected from flock.

Birds (150) from E1 (30 per treatment), and 144 birds from E2 (24 per treatment) were transported to the Laboratory of Meat Technology, FCA/ UFGD, and conventionally slaughtered. Carcass yield (\%), breast (\%) and thigh + drumstick (\%) were obtained after slaughter with reference to body weight $(\mathrm{kg})$ and hot carcass weight $(\mathrm{kg})$.

A completely randomized design was performed in E1 with five treatments: treatment 1 (yellow LED), treatment 2 (red LED), treatment 3 (blue LED), treatment 4 (White LED) and treatment 5 (Compact Fluorescent - control), with five replications of 54 birds each.

In experiment E2, a completely randomized design with a 3x2 factorial scheme (three light bulbs and both genders) was used, totaling six treatments: treatment 1 (red LED - male), treatment 2 (red LED - female), treatment 3 (Blue LED - male), treatment 4 (Blue LED - female), treatment 5 (compact Fluorescent - male), and treatment 6 (compact Fluorescent - female), with four replications of 54 birds each.

Data from both experiments were subjected to variance analysis (ANOVA) using ASSISTAT ${ }^{\circledR}$ statistical software (SILVA, 2012) and means compared by Tukey test at $5 \%$ probability.

\section{RESULTS AND DISCUSSION}

No difference was found among treatments for cumulative weight gain, feed intake, and feed conversion in E1 ( $\mathrm{p}>$ 0.05; Figure 1) and similar results were found by PAIXÃO et al. (2011). However, results from present experiment differ from that obtained by CAO et al. (2008) and ROZEMBOIM et al. (1999) for blue color LED. Our results disagree with those described by MENDES et al. (2010), as weight gain and feed convertion are higher for birds exposed to short wavelengths.

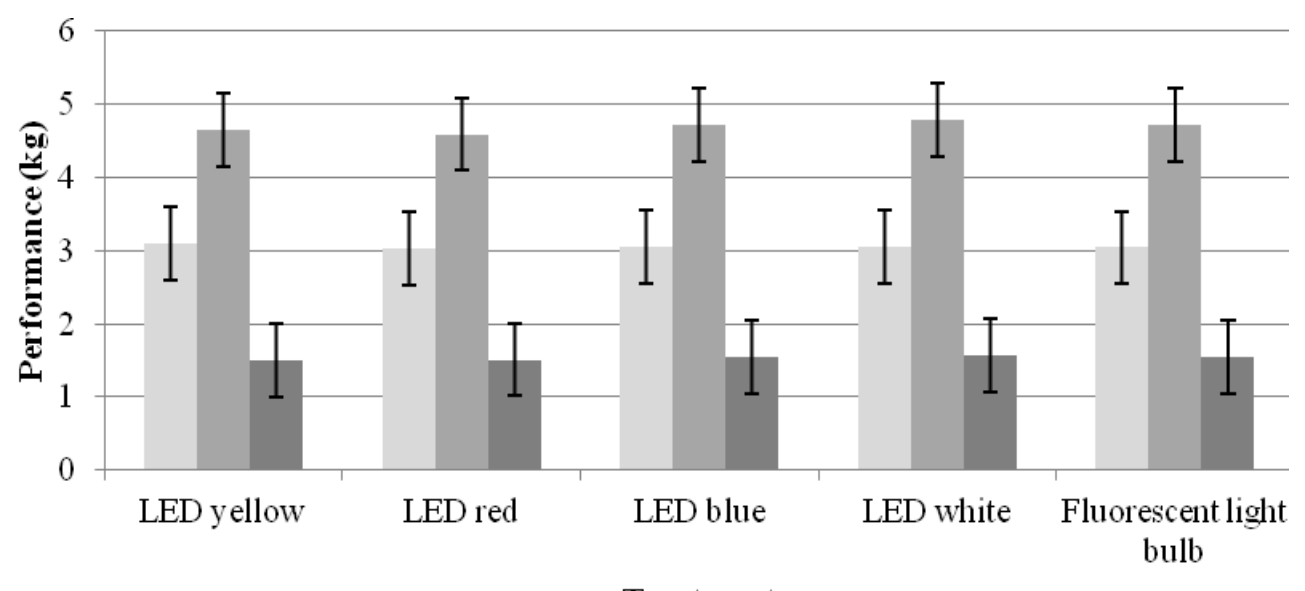

Treatment

Weight Gain $\quad$ Feed Intake $\quad$ Feed Conversion

ANOVA $(\mathrm{p}<0.05)$

FIGURE 1. Broiler productive performance $(\mathrm{kg})$ under LED artificial lighting compared to fluorescent lamp (E1).

Analyzing same variables in E2, results showed no differences ( $>>0.05$ ) for factor interactions (Table 1). No difference was found $(p<0.05)$ between genders and males showed higher cumulative weight gain and feed intake weight as found by various authors (STRINGHINI et 
al., 2003; MORO et al., 2005; GOMES et al., 2009). Feed conversion did not differ among treatments ( $p>0.05)$; however, differing from results presented by PAIXÃO et al. (2011), in which males presented higher feed conversion.

TABLE 1. Broiler performance subjected to two-color LED on artificial lighting compared to fluorescent lamp (E2).

\begin{tabular}{llll}
\hline \multicolumn{1}{c}{ Treatment } & \multicolumn{3}{c}{ Variable } \\
\cline { 2 - 4 } & WG $(\mathrm{kg})$ & FC $(\mathrm{kg})$ & CR \\
\hline Male & $3.117 \mathrm{a}$ & $4.837 \mathrm{a}$ & 1.55 \\
Female & $2.699 \mathrm{~b}$ & $4.344 \mathrm{~b}$ & 1.61 \\
\hline Red LED & 2.976 & 4.704 & 1.58 \\
Blue LED & 2.870 & 4.543 & 1.59 \\
Fluorescent light bulb & 2.878 & 4.526 & 1.57 \\
\hline VC (\%) & 5.10 & 4.56 & 4.95 \\
\hline
\end{tabular}

Average numbers followed by different letters in the column differ by Tukey test at $5 \%$ probability $(\mathrm{p}<0.05)$; VC $=$ variation coefficient; $\mathrm{WG}=$ weight gain; $\mathrm{FC}=$ feed conversion; $\mathrm{CR}=$ conversion rate.

No difference was found (p > 0.05; Figure 2) for hot carcass weight (kg), carcass yield (\%) and cuts (\%) among treatments. Hot carcass weight average was $2.305 \mathrm{~kg}$ for yellow LED; $2.298 \mathrm{~kg}$ for red; $2.242 \mathrm{~kg}$ for blue, $2.262 \mathrm{~kg}$ for white; and $2.308 \mathrm{~kg}$ for control. These results differ from those obtained by CAO et al. (2008), who found a greater carcass, breast, and thigh yield for broiler chickens subjected to blue LED artificial lighting. Our results may be related to used light program, agreeing with LIBONI et al. (2013), who found no differences in carcass and thigh yield of broilers when using continuous artificial lighting. When evaluating effect of different colors in artificial lighting for broilers, LIU et al. (2010) found that birds reared under green light had higher breast muscle weight than those reared under blue, red, and white light. Divergence among our results to the literature findings could be related to genetic strain and environmental conditions.

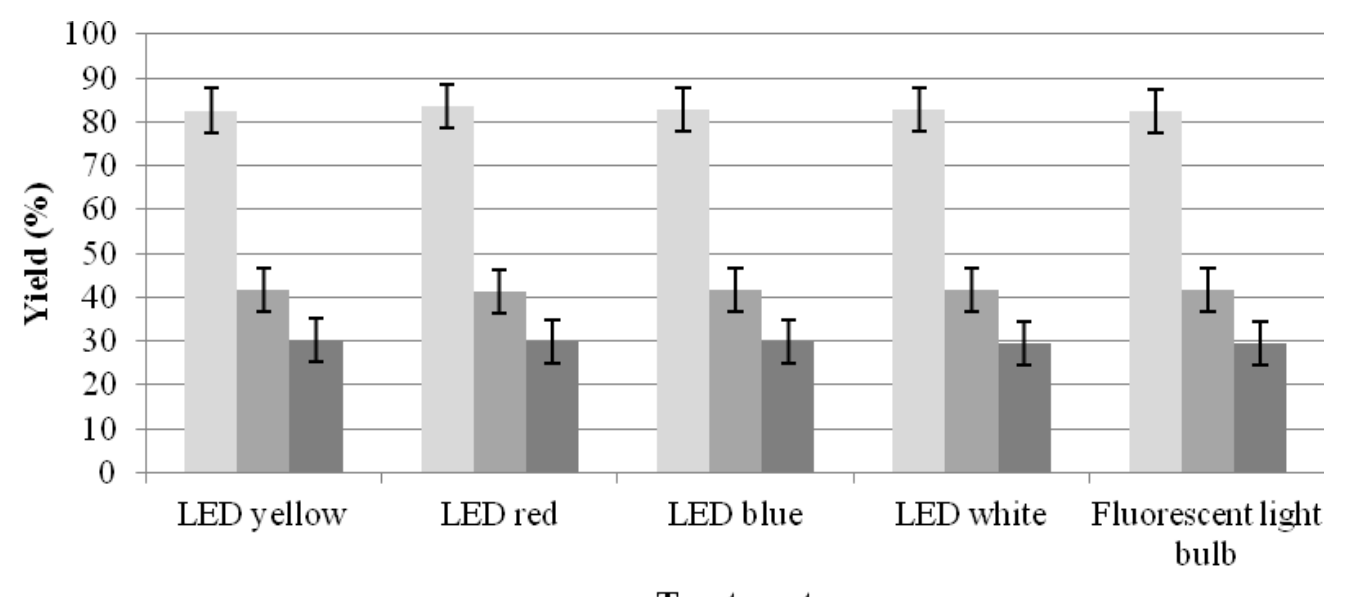

Treatment

Carcass $\quad$ Breast $\square$ Thigh/drumstick

ANOVA $(\mathrm{p}<0.05)$

FIGURE 2. Carcass yield and cuts (\%) of broiler chickens exposed to artificial LED lighting compared to fluorescent lamp.

In Table 2, it can be noted that the rates of carcass yield and cuts in E2 were influenced by gender $(\mathrm{p} \leq 0.05)$. Males showed higher thigh + drumstick $(29.36 \%)$ compared to females (28.36\%). A factor that affect carcass yield is the bird sex, because males have larger number of muscle fibers than females, resulting in higher thigh + drumstick yield (FARIA et al., 2010). As noted by CAO et al. (2012), LED monochromatic light combinations (green and blue) compared to 
a single light type use can increase broiler body, carcass, breast, and thigh weights and decrease feed conversion; thus, improving growth and yield performance.

TABLE 2. Broiler carcass yield and prime cuts subjected to two-color LED artificial lighting compared to fluorescent light bulb (E2).

\begin{tabular}{lcccc}
\hline \multirow{2}{*}{ Treatment } & \multicolumn{3}{c}{ Variable (weight and yield) } \\
\cline { 2 - 5 } & HCW $(\mathrm{kg})$ & Carcass (\%) & Breast (\%) & Thigh/drumstick (\%) \\
\hline Male & $2.250 \mathrm{a}$ & 72.35 & 42.92 & $29.36 \mathrm{a}$ \\
Female & $1.929 \mathrm{~b}$ & 71.84 & 43.29 & $28.36 \mathrm{~b}$ \\
\hline LED Red & 2.076 & 72.27 & 42.75 & 28.92 \\
LED Blue & 2.081 & 71.91 & 43.25 & 28.90 \\
Fluorescent light bulb & 2.110 & 72.10 & 43.32 & 28.77 \\
\hline VC (\%) & 8.21 & 2.46 & 9.11 & 6.11 \\
\hline
\end{tabular}

Average numbers followed by different letters in the column differ by Tukey test at $5 \%$ probability $(\mathrm{p}<0.05)$; VC $=$ variation coefficient; HCW=hot carcass weight.

\section{CONCLUSIONS}

The LED lighting in different colors, when compared to fluorescent light, did not impair broiler chicken growth performance parameters (weight gain, feed intake, and feed conversion) and carcass and cut yield (breast, thigh + drumstick). And considering energy efficiency, a key to sustainability, LED lighting may be suitable for poultry production.

\section{ACKNOWLEDGEMENT}

The authors wish to thank CAPES and CNPQ for research support.

\section{REFERENCES}

CAO, J.; LIU, W.; WANG, Z.; XIE, D; JIA, L.; CHEN, Y. Green and Blue Monochromatic Lights Promote Growth and Development of Broilers Via Stimulating Testosterone Secretion and Myofiber Growth. The Journal of Applied Poultry Research, Champaign, v.17, n.2, p.211-218, 2008.

CAO, J.; WANG, Z.; DONG, Y.; ZHANG, Z.; LI, J.; LI, F.; CHEN, Y. Effect of combinations of monochromatic lights on growth and productive performance of broilers. Poultry Science, Champaign, v.91, n.12, p.3013-3018, 2012.

FARIA, P.B.; BRESSAN, M.C.; SOUZA, X.R.; ROSSATO, L.V.; BOTEGA, L.M.G.; GAMA, L.T. Carcass and parts yield of broilers reared under a semi-extensive system. Brazilian Journal of Poultry Science, Campinas, v.12, n.3, p.153-159, 2010.

GOMES, P.C.; RIGUEIRA, D.C.M.; BRUMANO, G.; ALBINO, L.F.T.; ROSTAGNO, H.S.; SCHMIDT, M. Níveis nutricionais de zinco para frangos de corte machos e fêmeas nas fases de crescimento e terminação. Revista Brasileira Zootecnia, Viçosa, MG, v.38, n.9, p.1719-1725, 2009,

JIN, E.; JIA, F.; WANG, Z.; CHEN, Y. Effect of monochromatic light on transcription of opsin gene in the retinas and pineal glands of broiler. Chinese Journal of Animal and Veterinary Sciences, Xianyang, v.41, n.10, p.1306-1311, 2010.

LIBONI, B. S.; YOSHIDA, S. H.; PACHECO, A. M.; MONTANHA, F. P.; SOUZA, L. F. A.; ASTOLPHI, J. L.; ASTOLPHI, M. Z. Diferentes programas de luz na criação de frangos de corte. Revista Científica Eletrônica de Medicina Veterinária, Garça, v.11, n. 20, p.1-19, 2013.

LIU, W.; WANG, Z.; CHEN, Y. Effects of monochromatic light on developmental changes in satellite cell population of pectoral muscle in broilers during early posthatch period. Anatomical Record (Hoboken), NewYork, v.293, n.8, p.1315-24, 2010. 
MENDES, A.S.; PAIXÃO, S.J.; RESTELATTO, R.; MORELLO, G.M.; MOURA, D.J.; POSSENTI, J.C. Performance and preference of broiler chickens exposed to different lighting sources. The Journal of Applied Poultry Research, Champaign, v.22, n.1, p.62-70, 2013.

MENDES, A.S.; REFFATI, R.; RESTELATTO, R. PAIXÃO, S. J. Visão e iluminação na avicultura moderna. Revista Brasileira de Agrociência, Pelotas, v.16, n.1-4, p.05-13, 2010.

MORO, D.N.; ZANELLA, I.; FIGUEIREDO, E.A.P.; SILVA, J.H.S. Desempenho produtivo de quatro linhagens de frangos de corte. Ciência Rural, Santa Maria, v.35, n.2, p. 446-449, 2005.

PAIXÃO, S. J.; MENDES, A. S.; RESTELATTO, R.; MAROSTEGA, J.; SOUZA, C. DE.; POSSENTI, J. C. Desempenho produtivo de frangos de corte criados com dois tipos de lâmpadas. In: CONGRESSO DE CIÊNCIA E TECNOLOGIA DA UTFPR, 1., 2011, Dois Vizinhos. Anais... Dois Vizinhos: Universidade Tecnológica Federal do Paraná, 2011. p. 339.

PEREIRA, P. A.; YANAGI JUNIOR, T.; SILVA, J.P.; LIMA, R.R.; CAMPOS, A.T.; ABREU, L.H.P. Technical evaluation of artificial ligthing systems for broiler houses. Engenharia Agrícola, Jaboticabal, v.32, n.6, p.1011-1024, 2012.

ROZEMBOIM, I.; BIRAN, I.; UNI, Z.; ROBINZON, B.; HALEVY, O. The effect of monochromatic light on broiler growth and development. Poultry Science, Champaign, v.78, n.1, p135-138, 1999.

SILVA, F. A. S. Assistência Estatística - ASSISTAT (7.6 beta). Campina Grande. Departamento de Engenharia Agrícola Universidade Federal de Campina Grande, 2012.

STRINGHINI, J.E.; LABOISSIERE, M.; MURAMATSU, K.; LEANDRO, N.S.M.; CAFÉ, M.B. Avaliação do Desempenho e Rendimento de Carcaça de Quatro Linhagens de Frangos de Corte Criadas em Goiás. Revista Brasileira de Zootecnia, Viçosa, MG, v.32, n.1, p.183-190, 2003.

XIE, D.; CHEN, Y.; WANG, Z.; DONG, Y. Effects of monochromatic light on structure of small intestinal mucosa in broilers. Scientia Agricultura Sinica, Zhongguancun, v.42, n.3, p.1084-1090, 2009.

YANAGI JUNIOR, T.; AMARAL, A. G.; TEIXEIRA, V. H.; LIMA, R. R. Caracterização espacial do ambiente termoacústico e de iluminância em galpão comercial para criação de frangos de corte. Engenharia Agrícola, Jaboticabal, v.31, n.1, p.1-12, 2011.

ZHANG, L.; ZHANG, H.J.; QIAO, X.; YUE, H.Y.; WU, S.G.; YAO, J.H.; QI, G.H. Effect of monochromatic light stimuli during embryogenesis on muscular growth, chemical composition, and meat quality of breast muscle in male broilers. Poultry Science. Champaign, v.91, n.4, p.1026-1031, 2012. 